\title{
The Dialogue of Multicultural Education and Harmony in Prosperity Based on the Qur'an
}

\author{
Muhammad Yusuf 1, Achmad Abubakar ${ }^{2}$, Mardan ${ }^{3}$, Nahdhiyah 4, Abd Rahim 5 \\ 1 Sekolah Tinggi Agama Islam Al-Furqan Makassar, Indonesia \\ 2,3,4 Universitas Islam Negeri Alaudin Makassar, Indonesia \\ ${ }^{5}$ Universitas Agama Islam Negeri Watampone, Indonesia
}

Corresponding Author: Muhammad Yusuf, 0 muh.yusuf1274@gmail.com

\section{ABSTRACT}

This research aims to explore multicultural education dialogue and harmony in diversity based on the Qur'an. It aims to get anxious answers

ARTICLE INFO

Article history:

Received

July 11, 2020

Revised

November 07, 2020

Accepted

November 16, 2020

How to cite

Journal Homepage to various interpretations of the Qur'an, which then aims at understanding that is inclusive of the Qur'an. By conducting a thematic interpretation study with an anthropological approach, the concept of interpretation is found, which produces an inclusive understanding. It accepts diversity as sunnatullah by always maintaining tolerance and harmony in diversity. There are many Qur'anic verses which show that diversity is God's will as a test for humans to compete in goodness. Humans must realize tolerance, harmony, and cooperation, so it is necessary to form a collective agreement jointly. Therefore cross-faith and cultural dialogue must be carried out continuously by promoting ethics.

Keywords: Multicultural Education, Harmony in Propserity on the Qur'an Yusuf, M., \& Abubakar, A., Mardan, M., Nahdhiyah, N., \& Rahim, A., (2020). The Dialogue of Multicultiral Education and Harmony in Porsperity Based on the Qura'an. IJoASER (International Journal on Advanced Science, Education, and Religion), 3(3). 107-.119. https://doi.org/10.33648/ijoaser.v3i3.65 https:/ /ojs.staialfurqan.ac.id/IJoASER/

This is an open access article under the CC BY SA license https://creativecommons.org/licenses/by-sa/4.0/

\section{INTRODUCTION}

A person who endeavors to understand his religion without caring to understand the community can be radical. A Muslim sociologist, Professor Tahir Kasnawi stated, the effort and spirit to understand society without understanding religion correctly and will result in making someone liberal. In contrast, the lack of understanding of religion and culture leads someone to become a terrorist (Kasnawi, 2015). No matter how high religious teaching (Islam) exists, what exists in human life and influences society is its concrete implementation in history, namely humans' social and cultural life in space and time (Tahir, 2003: 2016-2017). If related to al-Qur'an, the context of makkiyah and madaniyah is not only a matter of place and time but also about the development of the Qur'anic ideas about the dynamics of society and human nature as social beings [4] who are cultured (Yusuf, Nahdhiyah, \& Ismail, 2019). The concept of makkiyah and madaniyah is a picture of the community's anthropology, which is a source of inspiration in understanding social dynamics on an ongoing basis (Yusuf, 2015).

It must first can capture the contents of messages and ideas in the scriptures. The concept offered by Nurcholish Madjid is by understanding textual facts of the al- 
Qur'an and al-Sunnah in such a way that what is shown is not only the outer meaning of the words of the holy text, but especially the "inner meaning" or "inward meaning" they contain (Madjid, 2000). To uncover the moral message of the Qur'an dealing with the sociocultural reality of society and diversity, it takes two simultaneous awareness in reading the text of the Qur'an (Solihin, Hasanah, \& Fajrussalam, 2020), namely historical understanding and reality awareness. The concept of socio-historical contexts must be adapted to the real context of community life.

In addition, awareness of reality is also needed. Generally, educational practices in two Islamic schools, contained teachings of religious and cultural diversity (Raihani, 2014). The dialectic of the historical context of the text with the socio-cultural reality attempts to make texts 'become alive'. In this regard, an anthropological approach is a must in understanding the texts. Through the anthropological approach, many Islamic issues are thoroughly explained (Nata, 200). Through an anthropologicalphenomenological approach, the relationship between religion and the state can be understood. The anthropological approach is one way to understand the Qur'an by understanding the form of Islamic practices that grow and develop in society (Mustaqim, 2017). The affirmation of the Qur'an that the story he published has a mission of enlightenment (Q.S. [7]: 175 \& [11]: 111With that method, humans can take the moral message in it, without feeling indoctrinated (Mustaqim, 2017). With this method, humans can take the moral message in it, without feeling indoctrinated ( Raharjo,1990). Stories are a pious approach to the Quran in understanding the reader that the text is limited and context is limited

\section{METHOD}

This study is using thematic method of Quran interpretation by applying an anthropological approach. Theoretically, the labeling of "thematic scientific works" refers to the varieties of methods and patterns of the Qur'an interpretation from the perspective of 'Abd al-Hayy al-Farmawī (1977). He was commonly referred as of the founders of a thematic method of Qur' an interpretation (Syarifuddin \& Jauhar, 2017: 43). This study concludes that at least there are three categories of thematic scientific interpretations of the Qur'an in Indonesia, namely: (1) works presenting general themes of scientific understanding, (2) works presenting thematic discussions on specific scientific perspectives, and (3) works seeking scientific understanding of the Qur'an as an evidence of its scientific miracles. In reading the sacred texts, it often produces the meaning of exclusivism because of neglecting the socio-historical background approach, both macro and micro contexts. Failure to capture text messages occurs when a reader separates the text from the context (Yusuf, 2020: \& Yusuf, 2014: 5). Once reality changes, Muslims' problems will also change that consist of the issues of humanity, human rights, justice, equality, peace, which will bring about an anthropocentric-transformative Islamic understanding (Wijaya, 2008). The scientific paradigms dynamics are experiencing the dynamics following the rhythm of time in every space and time.

Through an anthropological-phenomenological approach, the relationship between the religion and state, inter-religious, and cross-cultures can be understood. The anthropological-phenomenological plan looks at the relation of religion and the state, by involving historical awareness in interpreting the holy Qur'an to contextualize them in a real context. Harmony between the state and religion will be realized if the text is not separated from its history because every text has its history. The outer side of the text requires historical awareness and reality awareness for the interpreter. The 
Quranic texts have a particular background and a macro-historical background, namely the socio-historical background of the pre-Islamic Arab societies and the early Islamic period. The cultural situation in these two periods shaped the Qur'anic texts in response. The relationship between the text style and its meaning that is axiomatic cannot be doubted anymore (Abu Zaid, 2005). Interpreters must have broad insights and deep understanding to understand the meaning of the contents of these texts

\section{RESULT AND DISCUSSION \\ The Dynamics of Qur'anic Interpretation is a Must}

As illustrated above, some people's attitude also continues to deal with inclusive and contextual thinking. Those who hold to the paradigm of inclusiveness and contextualization of meaning continue to look for the relationship of the sacred text and its context. Al-Qur'an as a universal text of instructions and guidelines for humanity (hudan linnas), always contextual, let alone run out for review. The Qur'anic text can be interpreted richly, depending on the socio-cultural context and the structure of values or awareness of its readers ( Abu Zaid, 2005). Because of the vastness of its meaning, Abdullah Darras likens the wealth of the Qur'an like diamonds. Each corner emits light that is different from what emanates from other angles. It is not impossible if people are welcome to see from another angle that will emit a different meaning from another angle. One will see many different things if done objectively (Shihab, 2000: xv). By connecting the text and its context, the Qur'anic texts 'are always new' in dealing with social dynamics that occur continuously.

When science normally runs, a period of knowledge accumulation in which scientists work and develop an influential paradigm. Eventually, scientists cannot avoid a paradigm shift that causes a crisis. In such conditions, the old model is again disturbed, and its validity is questioned. A paradigm revolution is inevitable, so thinkers work to reconstruct a paradigm to answer contemporary problems that cannot be overcome by the old model. Like it or not, there was a significant change or revolution in science (Ritzer, 2004: 5 \& Kuhn, 2002). The inherent characteristic of science is dynamics. Interpretation as a discipline also experiences dynamics in tune with the context of changes that occur.

Efforts to dialogue between Islam and science necessitates a paradigm movement following human needs to overcome and answer the problems faced in every space and time. The position of religion (Islam) must also be able to meet the expectations of its adherents. It requires that Islam be translated in every context of space and time. Islamic understanding in each space and time depends on the problems faced by the people (Hanafi,1989). If interpretation is a knowledge that does not want to be abandoned, then adapting to humanity's needs is necessary.

\section{Anthropological Approach in Responding to Pluralism}

The anthropological approach will dialect between the written text and the community's behavior, building relationships between the text and the community's socio-cultural context. The sacred text position is to correct the inhumane practice of the community according to the standards of the Qur'an and strengthen the position of the practice of society, which is in line with Divine guidance. In addition to seeing the community's religious traditions and culture, the anthropological approach also Abuddin Nata said that through the anthropological-phenomenological approach, the relationship between religion and the state (Nata, 2004). The anthropological- 
phenomenological approach can be used to see the relationship between religions and the Republic of Indonesia.

In the Qur'an, there is an order from Allah to the Prophet to invite the Ahl alKitab to unite in the common ground (kalimatun sawa'), which is the understanding of Godhead. Based on Q.S. Ali Imran [3]: 64., the core of all true religions is monotheism or belief in God Almighty. Every grouping of people has received teachings about the divinity of the One (Ketuhanan Yang Maha Esa) through the apostles of God (Nurhadi, 2019). Therefore, there is a meeting or agreement point (kalimatun sawa') between all human religions. Muslims are instructed to develop the meeting point as a basis for living together in diversity (Madjid, 2000). Although it is very logical, a note accompanies God's command that if the other party refuses to meet in a point of similarity, then we must uphold our own identity as people who surrender to God. Still, the basic principle of that command shows always to be endeavored to carry out throughout the ages.

Life in pluralism had been done by people before, namely, on the structural and political aspects by the Prophet. He always sought a meeting point (agreement) with various Medina groups by first recognizing each group's right of existence in the famous document "Medina constitution." Umar bin Khattab continued the Prophet's sunnah in his attitude towards the inhabitants of Jerusalem, in a document that came to be recognized as the Aelia charter (because Jerusalem was also known as Aelia). Then continued the Umawi caliphs in Andalusia (Spain), even the pluralistic politics brought by Muslims to Spain, was described by Max Dimont as a blessing that ended Christian religious tyranny. After a 500-year Islamic government created a Spanish for three religions and "one bed": Muslims, Christians, and Jews lived in harmony and accompanied a glorious civilization (Madjid, 2000). The pattern that was once practiced at the historical level, plurality is a rule of God (sunnatullah) that will not change, so it is impossible to be opposed or denied. Islam is a religion whose sacred books expressly recognize other religions' rights, except those based on shirk or paganism (Madjid, 2000).

It should not be surprising that Islam, as the last religion, claims to be the religion, which has fostered the growth and development of religions along that continuity line. Islam's final solution as the previous religion for religious matters is the teaching of recognition of these religions' rights to exist and be implemented. Therefore, not only religion should not be forced (Q.S. Al-Baqarah/2: 256, and Q.S. Yunus/10: 99), even the Qur'an also implies that adherents of various religions, provided that they believe in God and later days and do good, everyone will be safe (Madjid, 2000: xxviii). honestly believe in Allah, days later and do good deeds, they will receive merit from their Lord, there is no concern for them, and neither (nor) they grieve (Q.S.. al-Baqarah/2: 62).

In pluralism, adherents of religions in Indonesia must build communication and understanding across religions for the realization of harmony, tolerance, and cooperation. Cultural diversity must be accepted as a fact in Indonesia (Parlindungan, et.al., 2018: 289-302). Belief should carry out its function as teaching that leads to social and spiritual order. As most in number, Muslims must be most ready to bridge or mediate communication and cooperation in cultural and religious diversity. Similarly, adherents of other religions. The relationship between religion and the State, community relations, and the State must be a priority in addressing this diversity.

The diversity of religions and beliefs and schools of thought is a necessity and an absolute. It can be seen in several verses in the Qur'an. If God's wills, indeed, you 
will be made into a single person, but God wants to test you against His gifts and compete to do good. Only Allah returns all of you, and He tells you what you have disputed (Q.S. al-Māidah/5: 48). And if your Lord wills, indeed, everyone in the entire earth has faith. Do you want to force people to become believers? (Q.S. Yunus/10: 99). And if your Lord wills, indeed, He will make people of one person, but they always disagree (Q.S. Hūd/11: 118). And if Allah wills, He will make you a people (only), but Allah deceives who He desires and gives instructions to whom He wants. And you will be asked what you have done (Q. al-Nahl/16: 93). And if Allah wills, Allah will make them one person (only), but He includes the people He wants into His grace. And those who do wrong do not exist for them as protectors or helpers (Q.S. alSyūrā/42: 8).

In terms of language study, the letter or device "if/law" in these verses is called the surah imtinā' (impossible to happen). Fulfillment of requirements indicates whether an answer is fulfilled or something is fulfilled (Ni'mah, n.d. 177). Regarding the verses above, the letter, the law shows something reality that something does not happen. Q.S. Yūnus/10: 99 expressly states that the diversity of faith becomes God's will, even very explicitly stated that if God wills, all of His servants will be uniform in their faith. However, the fact is that humans have non-uniform faith.

The pattern of Quranic verses shows that religious plurality is a necessity that happens by the will of Allah. It is understood from the use of the law (if only) in the editorial: ولو شاء الله لجعلكم أمة واحدة "if God wills, you will only be made by the people" shows that he didn't want to because the word law is not used in this context except to presuppose something impossible. It means God did not want to make all human beings from the past until now only one person, namely one opinion, one tendency, even one religion in all its principles and details. If God so desired, He would not give humans the freedom to sort, including the freedom to choose faith and belief. Freedom to sort and select is intended so that humans compete well in virtue, and thus there will be creativity and quality improvement (Shihab, 2001).

In building harmony between religious adherents, absolution does not have to be announced out, but inwardly, it must be each follower's belief following Q.S. Sabā '/ 34: 24-26. When religious absolutes were delivered to the public, the Prophet Muhammad did not instruct to state what is in the belief about the absolute truth of Islam's teachings. But instead, on the contrary, the content of the verse is like expressing: "Maybe we are right, maybe you are too. Maybe we were wrong, maybe you are. We leave it to God to decide" (Shihab, 2001).

The verses stated above provide clear instructions regarding the relationship between religious adherents or between religious believers. Every human being has right to choose a particular religion, regardless of religion and belief, because the core of religiosity is the human relationship with something outside of himself that is believed to influence, namely the danger and benefit in a person. Thus, polytheism was adopted by Meccan pagan at the beginning of Muhammad's apostolic mission, also called religion.

\section{Starting from the Recognition of Existence}

Recognition of existence as a result of cultural and religious diversity, for Muslims, there is no problem, because Islam indeed from the beginning did not make religious differences to discriminate against someone. As confirmed in Q.S. alMumtahanah/60: 8-9. The Qur'an does not make religious differences as an excuse not to establish cooperative relations, let alone take unfriendly attitudes and be 
discriminatory towards someone on the grounds of religious differences. Even the Qur'an does not forbid Muslims to do good and give part of their wealth to anyone, including non-Muslims, as long as they do not fight Muslims with religious motivation or expel Muslims from their country (Shihab, 1996). When Prophet has just received a revelation from God through the angel Gabriel, at first, he was filled with fear and anxiety, so he went straight to his house in a state of trembling and asked to be enveloped by his wife, Khadijah r.a. As a result, the fear and anxiety experienced can be muted by Khadijah who succeeded in entertaining and convincing the Prophet., by stating: Cheer up, my uncle's son, resolve your heart, for the sake of God whose soul Khadijah is in His hands, I hope you will be a Prophet of our people. God will not disappoint you, are you not the one who always helps orphans, glorifies guests, and helps everyone afflicted by misery and misery? (Departemen Agama RI., 2002: 54).

Furthermore, to further solidify his soul about the events he had just experienced, he was brought by Khadijah to face Waraqah bin Naufal. He was a religious figure in Mecca with a Christian background; he was known to have extensive knowledge of Christianity and mastered Hebrew. He has also studied and translated the Torah and the Gospels into Arabic. When the Prophet explained to Waraqah the events he had just experienced, Waraqah stated: "For the sake of Him whose soul I am in His hands, surely you are the Prophet of this people. Verily, what came to you was al-Namus al-Akbar (the angel Gabriel), who also came to Moses. Surely you will certainly be denied, tortured and fought. If I were still alive at that time, surely, I would defend those who are on the side of God and the defense that he knows" (Ibn Hisyām, 2001 \& Haikal, 2015).

The Waraqah statement was moral support for Muhammad to continue his da'wah. Although Waraqah was known as a religious figure and adherent of Christianity, it seems that Mecca's inhabitants were not very interested in Christianity's teachings, so there was no Christian community in Mecca at that time. The inhabitants of Mecca are generally known as pagan communities. Therefore, the first community that directly came into contact with the mission of monotheism that he brought was a community that was a polytheist. Since then, the rejection of Muhammad's mission began, especially from the elite group of Quraysh. The rejection of its mission is more focused on the implications of the monotheistic creed rather than the economic and political aspects that directly interfere with the period's economic and political joints. From the start, a part of Mecca's elite offered cooperation, especially in religious rituals, but was expressly rejected by the Prophet Muhammad. With that emphasis, although differences occur there should not be a conflict because what is requested by the Prophet is the recognition of the teachings he carries and the freedom to explain religious teachings following Islamic beliefs, the Quraysh elite never accepted the request until the Prophet migrated to Medina.

Intolerant attitude and hostility showed by the Quraysh elites in towards the Prophet and his followers. They acted in the form of insults to the Prophet and torture outside the boundaries of humanity's fairness aimed at his companions. When he saw the suffering suffered by some of his friends and avoided the persecution carried out by the polytheists of Mecca, the Prophet recommended that they emigrate to Ethiopia where the people adhered to Christianity (Ibn Atsir, 1965). It was done because the Prophet received information that the Ethiopian ruler al-Najjāsyi was known as a just ruler.

Even though the Prophet himself did not migrate to Ethiopia, friends who migrated to the Christian community area received proper protection from the 
Ethiopian authorities (Ibn Hisyam, 2001). It was only then that the companions returned to Mecca after obtaining information that the Quraysh elite had changed their perceptions of the Muslims. Still, it turned out that after they returned to Mecca, the pressure exerted on Muslims was getting more robust. After various efforts made by the Prophet to establish cooperation with communities outside of Islam, including the ruler of Thaif, failed, the Prophet finally moved to Medina after there was a guarantee from two tribes in Medina, namely Aus and Khazraj.

\section{The Social Function of Mosques as a Means of Building Harmony and Peace}

The first step undertaken by the Prophet in Medina with his friends after arriving in Medina was to build a mosque as a center for the development of the ummah in its broadest sense, to further carry out the internal consolidation of Muslims by making the Muhajirin and the Ansar, the brothers. The function of mosque is not only as a ritual facility (formal prayer such as prayer) but also as a center to build peace. That is also, among other things, the secret behind the journey of the Isra. The Prophet started from Masjidil Haram in Mecca to the Masjidil Aqsa in Palestine, so that the mosque was used as an instrument to build internal dialogue and inter-faith religion. The mosque contains human values in the form of peace between human beings.

The next step is to collaborate with all components of the Medina community to build a city-state. The result was the creation of the Medina Charter (Ibn Hisyam, 2001). Inter-religious relations in the period of Prophet Muhammad were running in harmony (Patmawati, 2016). Now Madinah is historical documentation of the effects of interfaith cooperation initiated by the Prophet. The formulation of the agreement in the Medina Charter is a constitution that regulates plural life (Mubasyaroh, 2014). Based on 47 articles listed in the Medina Charter, according to Munawir Syadzali, the charter has laid the foundations for the life of the state for plural society in Medina. First, all adherents of Islam, although coming from many tribes but are one community. Second, relationships between fellow Islamic communities internally and between fellow members of the Islamic community and members of other communities are based on the principles of a. Good neighbor; b. Help each other in dealing with common enemies; c and defending the persecuted; d. Counseling one another; e. Respect for religious freedom (Syadzali, 1990 \& Nurhakim, 2016).

The text of the constitution is exciting because it contains points of thought, which are also impressive from modern observations. In the constitution, for the first time, it was formulated ideas that now became current life views, such as freedom of religion, the right of each group to regulate life following their beliefs (Jania, et.al, 2015), independence of economic relations, and other aspects. But it also stressed the existence of a general obligation, namely participation in joint defense efforts to deal with enemies from outside (Madjid, 1983).

The implementation of the Medina Charter contents gave rise to quite intensive social interaction among Madinah residents with different religious and cultural backgrounds. The Jews lived side by side with Muslims peacefully, and over time there was an intense meeting between the two; eventually, there was also an exchange of knowledge between them Rasulullah Saw sometimes meet Jews and other communities to convey Islam. Conversely, Jews also often come to the Prophet to solve a problem in them, or occasionally want to ask a few questions (Al-Dhahabì, 1986).

Religious differences in the first years of the Prophet and the Muslims in Medina did not prevent them from engaging in intensive interactions in social life. In 
developing science for Muslims and the transformation of civilization, the Prophet once appointed a secretary with a Jewish background. It is necessary because the Jews are proficient in Hebrew and Syriac language. Zaid bin Thabit only replaced him after Banu Nadzir was driven out of Medina (Ibn Hisyām, 2001). Contact between Islam, the Jewish, and Christian communities have been established since the Prophet Saw was appointed as an apostle. However, intensive contact, especially with the Jewish community, after the Prophet emigrated to Medina (Willya, 2012). At that time, these two communities already existed in the Arabian Peninsula region. The Ahl al-Kitāb from the Jewish community had strong positions in Medina and Khaibar. At the same time, Christianity had an important influence on Najran. In the process of interaction between the Prophet and his companions with the Jewish and Christian communities, it happened well because the relationship was fostered on good ethics. The point that was emphasized is that the relationship with Ahl al-Kitab must be maintained because it is by the guidance of the Qur'an.

Indonesian Muslims have thousands of mosques throughout Indonesia. The number continues to increase along with the increase in the number of Muslim settlements. Almost every new complex of opened changes is a package with a mosque or at least a location for the preparation of worship facilities (mosque). If managed properly, it will function as a means of building social integration apart from worship (Kamaruddin, 2013; Hidayat, 2014). To empower awareness of togetherness, harmony, and productive efforts for the common welfare, it is urgent to promote peace and harmony are mosque-based (Dalmeri, 2014). The state goal is to present inner and outer welfare can only be realized if supported by peace and harmony between people.

\section{Formulating A Cross-Understanding and Collective Agreement}

The search for common ground must pass through the door of ethics (Yetkin, 2009). Ethics is the fundamental doctrine of all religions so that it can become a meeting point in the process of dialogue. As for the institutions, formalities, dogmas, and rituals of religion, it is a sensitive matter to be touched. It is impossible to be equalized because every religion has unique teachings (typical values). Unlike the case with ethical issues and all human beings' needs, ethics is also a universal doctrine (universal values) of every religion that must be communicated continuously. It supports several views. Eka Darmaputra wrote: "The enemy of religion is actually, and the devils are the common enemy and the main enemy of all religions. When religion succeeds in defeating the institutionalism, formalism, dogmatism, and ritualism traps, and subsequently takes ethical care seriously, the door to dialogue and cooperation between religions opens wide" (Darmaputra, 1997).

The search for common ground is held through encounters and dialogue for constructive and sustainable meetings of ideas is possible in various ways, including through the 'ethical entrance.' Maussen and Grillo show the existence of linguistic contexts that exist to avoid the forms that cause differences that lead to disputes. By taking research sites in Europe, both concluded that mutual understanding became a framework to encourage interaction between citizens in the community (Maussen \& R. Grillo, 2014).

Indonesian society is surrounded by mutual respect between followers of religion and ethnicity. It is encouraged because of the emergence of a sense of brotherhood that forms harmony and a conducive environment (Mujahidah, 2010). Because of the 'gateway to ethics,' religious people universally face the same humanitarian challenges. Through this 'ethical gateway,' first, religious people feel 
they have the same peaks. Second, religious adherents can be touched by their "religiosity," not only to emphasize having their religion. Third, the dimension of orthodox spirituality is more pronounced promising and challenging and not just focused on the outward aspects of religious institutional formality (Abdullah, 2004; Setiawan et al., 2020).

These three aspects lead to an agreement that results in tolerance, harmony, and even interfaith cooperation amidst diversity. Geertz concluded that socialization in the community would be an opportunity to develop this understanding (Geertz, 1963). In comparison, Harbison and Myers believe that the element that sustains society's harmony is human formation as the principal capital. These individuals always promote collaboration, the importance of establishing positive relationships, and persuasive communication (Harbison \& C. A. Myers, 1964) to realize harmony in a heterogeneous society. Three studies conducted by Chua explain this condition regarding the formation of harmony and peace that starts from an idea and an agreement point (Chua 2013 \& Q.S. al-A'raf/13:11). This view is similar to the Prophet's practice when the process of formulating the 'Medina Charter' by inviting all religious elites and ethnic leaders together agree as outlined in the 'Medina Charter.'

The expected outcome of dialogue through 'the ethical gateway' by Muslims from all parties, including Ahl al-Kitäb, is kalimatun sawa' (cross understanding). If this is not found, then it is sufficient to acknowledge Muslims as religious people. They are not disturbed and hindered to carry out worship (Shihab, 1996). In the Indonesian state (Asfina \& Ririn, 2016), this is also following the Unitary Republic of Indonesia's ideals as mandated by the UUD 1945, article 29 paragraph 2 and in line with sura al-Kafirun. The ritual (technique) teachings cannot be forced and must be understood as the private area of each religion. Each religion in the world has typical values that only exist in each religion, and each religion has a universal value that is believed by all faiths. Such values are called universal values (Yakin, 2005). In initiating dialogue, what needs to be developed is the universal values of each religion, not its particular values. Dialogue aims to achieve two things; first, equality and agreement and second, tolerance and cooperation. Dialogue should be carried out for getting "agreement" on universal values and "tolerance" on particular values. That is, among other things, the intention of Q.S. al-Kāfirūn/109.

Universal values in Islam' teachings include truth, justice, prosperity, maintain relationships with fellow human beings, relationships with God, do not act arbitrarily to others, help each other, respect each other, and love one another. In Catholic teachings, we found universal teaching values about truth, justice, the welfare of humanity, the love of love, maintaining harmony with God, and between humans and other humans. In Protestantism, there is a teaching of universal value, which is ordered to follow Christian moral instructions for its adherents; that is, upholding morals to do good deeds and avoid evil deeds to live eternally in heaven and avoid hell. These universal values need to be socialized and communicated to seek cooperation and tolerance agreements. Harmony can only be achieved if it does not impose particular values on each religion (Yakin, 2005). It is following the Qur'an, which teaches that absolution does not have to be announced out, but of course, it must be the belief of each adherent under Q.S. Sabā'/34: 24-26.

Dialogue between religious believers is necessary for religious communities throughout the ages, so it is carried out continuously. Failure to establish dialogue often occurs, and religious conflicts arise because the dialogue occurs when there is a conflict, so the focus is on some instances. Communication should be fostered 
continuous so that dialogue is not reactive and temporal, but rather proactive and sustained. It is what sometimes escapes the attention of the government and the elites of every religion. It is also crucial to pay attention to the cultural roots of each region which is sensitive - which often becomes the seeds of conflict. Religion can play a dual role with regard to conflict. It can promote either violence or peace (Francis, Chris A.M. Hermans, \& Carl Sterkens, 2015). Houses of worship, including mosques, are the most appropriate means of promoting peace and peace amidst diversity by promoting ethics and seeking common ground.

\section{CONCLUSIONS}

Understanding the Quranic text on diversity, multi-cultural dialogue, inter-faith dialogue, tolerance, cooperation can be understood by tracing the Prophet's practices with friends, especially in Medina. It is in this context that the anthropological approach finds its relevance in understanding verses about diversity. The expected outcome of dialogue through 'the ethical gateway' by Muslims from all parties, including Ahl al-Kitāb, is kalimatun sawa' (cross understanding). If this is not found, then it is sufficient to acknowledge Muslims as religious people. They are not disturbed and hindered to carry out worship. In the Indonesian state, this is also following the Unitary Republic of Indonesia's ideals as mandated by the UUD 1945, article 29 paragraph 2 and in line with sura al-Kafirun. The ritual teachings cannot be forced and must be understood as the private area of each religion. Every religion in the world has typical values that only exist in each religion, and each religion has a universal value that is believed by all faiths. Such values are called universal values. In initiating dialogue, what needs to be developed is the universal values of each religion, not its particular values. Dialogue aims to achieve two things; first, equality and agreement and second, tolerance and cooperation. Dialogue should be carried out for getting "agreement" on universal values and "tolerance" on particular values. Universal values in Islam' teachings include truth, justice, prosperity, maintain relationships with fellow human beings, relationships with God, do not act arbitrarily to others, help each other, respect each other, and love one another. In Catholic teachings, we found universal teaching values about truth, justice, the welfare of humanity, the love of love, maintaining harmony with God, and between humans and other humans. These universal values need to be socialized and communicated to seek cooperation and tolerance agreements. Harmony can only be achieved if it does not impose particular values on each religion. It is following the Qur'an, which teaches that absolution does not have to be announced out, but of course, it must be the belief of each adherent. The dialogue between religious believers is necessary for religious communities throughout the ages, so it is carried out continuously. Failure to establish dialogue often occurs, and religious conflicts arise because the dialogue occurs when there is a conflict, so the focus is on some instances.

\section{ACKNOWLEDGEMENTS}

We express our gratitude and appreciation for the trust that has been given by the IJoASER Journal that help to maximize a good article thourgh peer-review process Thank you for all participants in this research and authors for good cooperation and contributions in this research. Thank you also expressed to all aassistants gives more contribution. 


\section{AUTHOR CONTRIBUTION STATEMENTS}

The first author has contributed to providing references, collecting data, and translating into English. The first author also conducted correspondence with the editor from submission to publication of this article. Other authors also contributed to the provision of data sources and analyzes. The authors, as a whole, were involved in discussing many things related to this article.

\section{REFRENCES}

Abdullah, Amin. (2004). "Etika dan Dialog Antar Agama, Perspektif Islam, dalam Elga Sarapung", et.al., Dialog: Kritik \& Identitas Agama. Yogyakarta: institut DIA/Interfidei. Google Scholar

Abu Zaid, Nasr Hamid. (2005). Mafhum al-Nash Dirasah fi 'Ulum al-Qur'an. Trans. Khoiron Nahdhiyin, Yogyakarta" LKiS. Google Scholar

Al-Dzhabai, Muhammad Husain. (1986). Al-Isrā'īliyyat fī al-Tafsīr wa al-Hadìth. Kairo: Maktabah al-Wahbah. Google Scholar

Anthony, Francis-Vincent, Chris A.M. Hermans, \& Carl Sterkens. (2015). “Interpreting Religious Plurality" In Religion and Conflict Attribution, Series: Radboud Studies in Humanities 3 Brill, 117-142. Google Scholar

Asfina, Risda \& Ririn Ovilia. (2016). "Be roud of Indonesian Cultural Heritage Richness and Be Alert of its Preservation Efforts in the Global World". Humanus 15(2), 195-206. https:/ / dx.doi.org/10.24036/jh.v15i2.6428

Chua, Roy. Y. J. (2013). "The Costs of Ambient Cultural Disharmony: Indirect Intercultural Conflicts in Social Environment Undremine Creativity". Academy of Management Journal 56(6), 1545-1577. https:// doi.org/10.5465/amj.2011.0971

Dalmeri. (2014). "Revitalisasi Fungsi Masjid sebagai Pusat Ekonomi dan Dakwah Multikultural". Jurnal Walisongo 22(2), 321-350. https:// doi.org/10.21580/ws.22.2.269

Darmaputra, Eka. (1997). “Tantangan terhadap Penghayatan Agama Dewasa ini dan Alternatifnya di Masa Depan: Musuh Agama Bukan Musuh Sesama Agama tetapi Syaitan-Syaitan". Penuntun 3(11), 260. Google Scholar

Departemen Agama RI. (2002). Al-Qur'an dan Terjemahnya. Jakarta: n. p. Google Scholar

Geertz, Clifford. (1963). "The Integrative Revolution: Primordial Sentiments and Civil Politics in the New States" in Clifford Geertz (Rev.)". Old Societies and New States: The Quest for Modernity in Asia and Africa. New York: Free Press. Google Scholar

Haikal, Muhammad Husain. (n.d.). Hayātu Muhammad. Kairo: Dār al-Ma'ārif.

Hanafi, Hasan. (1989). al-Din wa al-Tashwirah fi Mishr: 1952-1981, al-Yamin wa alYasar fi al-Fikr al-Diniy. Kairo: Maktabah al-Madbuliy.

Harbison, F. \& C. A. Myers. (1964). Education, Manpower, and Economic Growth. New York: McGraw-Hill. Google Scholar

Hidayat, Arif. (2014). "Masjid dalam Menyikapi Peradaban Baru". Ibda': Jurnal Kebudayaan Islam 12(1), 13-26.

Ibn Athir. (1965). Al-Kāmil fī al-Tārīkh. Jilid II, Beirūt: Dār al-Fikr.

Ibn Hisyām. (2001). Al-Sīrah al-Nabawiyyah. Beirūt: Dār Ibn Hazm.

Jania, Haza Hanurhaza Md, Nor Zalina Harunb, Mazlina Mansorc, Ismawi Zend. (2015). "A review on the medina charter in response to the heterogeneous society in Malaysia", Procedia Environmental Sciences 28 (2), 92 - 99. https:// doi.org/10.1016/j.proenv.2015.07.014 
Kamaruddin. (2013). “Analisis Potensi Pemberdayaan Ekonomi Masyarakat Berbasis Masjid di Kota Banda Aceh". Jurnal Ilmiah Islam Futura 13(1), 58-70.

Kasnawi, Tahir. (2015). "Modernisasi Pemikiran Islam di Indonesia". National Seminar. November 21, 2015 at Wong Solo Seminar Room Jl Sultan Alauddin Makassar.

Kuhn, Thomas S. (2002). The Stucture of Scientific Revolution: Peran Paradigma dalam Revolusi Sains. Bandung: Rajawali Press. Google Scholar

Madjid, Nurcholis. (2000). Islam Doktrin dan Peradaban. Jakarta: Paramadina. Google Scholar

Madjid, Nurcholish. (1983). Cita-cita Politik Kita, dalam Bosco Carvallo \& Dasrizal (ed), Aspirasi Umat Islam Indonesia. Jakkarta: Leppenas. Google Scholar

Maussen, M. \& R. Grillo. (2014). "Regulation of Speech in Multicultural Societis: Introduction". Journal of Ethnic and Migration Studies 40(2), 174-193. https:// doi.org/10.1080/1369183X.2013.851470

Mubasyaroh. (2014). "Da'wah Model of Prophet Muhammad In Medina". QIJIS: Qudus International Journal of Islamic Studies 2(1), 47-62. Google Scholar

Mujahidah. (2010). “Analisis Terhadap Interaksi Sosial Antar Pemeluk Agama dan Etnis di Kota Sorong". An Individual Research Report. STAIN Sorong.

Mustaqim, Abdul. (2017). "Kisah al-Qur'an: Hakekat, Makna, dan Nilai-Nilai Pendidikannya". Ulumuna, 15(2), 265-290. Google Scholar

Nata, Abuddin. (2014). Metodologi Studi Islam. Jakarta: PT RajaGrafindo Persada. Google Scholar

Ni'mah, Fuad. (n.d.). Mulakhkhash Qawā'id al-Lugah al-'Arabiyyah. Juz 1, Beirūt: Dār al-Tsaqāfah al-Islāmiyah.

Nurhadi. (2019). “Ideologi Konstitusi Piagam Madinah dan Relevansinya dengan Ideologi Pancasila". Volksgeist 2(1), 107-129. Google Scholar

Nurhakim, Agus. (2016). "City-State (Medina) and Its Implementation in the Republic of Indonesia". International Journal of Nusantara Islam 04(02), 37-48. Google Scholar

Parlindungan, Firman, Irfan Rifai, \& Afida Safriani. (2018). “The representation of Indonesian cultural diversity in middle school English textbooks". Indonesian Journal of Applied Linguistics 8(2), 289-302. Google Scholar

Patmawati. (2016). "Inter-Religious Relation in the Period of Prophet Muhammad". AlAlbab 5(2), 175-193. Google Scholar

Raharjo, Dawan. (1990). "Pendekatan Ilmiah terhadap Fenomena Keagamaan" in Taufik Abdullah dan M. Rusli Karim. Metode Penelitian Agama. Yogyakarta: Tiara Wacana.

Raihani. (2014). "Islamic Education and The Multicultural Society: Description of Education for Cultural Diversity in Two Islamic Schools in Indonesia". JICSA 03(02), 1-23. Google Scholar

Ritzer, George. (2004). Sosiologi Pengetahuan Berparadigma Ganda. Trans. Alimandan, Jakarta: Rajawali Press.

Solihin, I., Hasanah, A., \& Fajrussalam, H. (2020). Core Ethical Values of Character Education Based on Islamic Values in Islamic Boarding Schools. International Journal on Advanced Science, Education, and Religion,3(2), 21-33. https:// doi.org/10.33648/ijoaser.v3i2.51

Setiawan, T., De Jong, E. B., Scheepers, P. L., \& Sterkens, C. J. (2020). The relation between religiosity dimensions and support for interreligious conflict in 
Indonesia. Archive for the Psychology of Religion, 42(2), 244-261. https:// doi.org/10.1177\%2F0084672419878824

Shihab, M. Quraish. (1996). Wawasan al-Qur'an. Bandung: Mizan.

Shihab, M. Quraish. (2000). Tafsir al-Misbah: Pesan, Kesan, dan Keserasian Alquran. Jilid I, Jakarta: Lentera Hati.

Shihab, M. Quraish. (2001). Tafsir al-Mishbah, Pesan, Kesan dan Keserasian al-Qur'an. Vol. 3, Jakarta: Lentera.

Syadzali, Munawir. (1990). Islam dan Negara, Ajaran, Sejarah dan Pemikiran. Jakarta: UI-Press.

Syarifuddin, M. Anwar \& Jauhar Azizy. (2017). “Thematic Scientific Interpretation of the Qur'an in Indonesia". International Conference on Qur'an and Hadith Studies (ICQHS) on Advances in Social Science, Education and Humanities Research (ASSEHR) 137(03), 43. https:/ / dx.doi.org/10.2991/icqhs-17.2018.7

Tahir, Lukman S. (2003). Studi Islam Interdisipliner; Aplikasi Pendekatan Filsafat, Sosiologi, dan Sejarah. Yogyakarta: Qirtas. Google Scholar

Wijaya, Aksan. (2008). "Paradigma Baru Wacana Agama: Melepaskan Agama dari Bayang-Bayang Lembaga, Organisasi, dan Aliran Keagamaan". Millah: Jurnal Studi Agama Pascasarjana UII 7(2), 1-22. Google scholar

Willya, Evra. (2012). Pemikiran Thabathaba'i tentang Fikih Antar Umat Beragama dalam Tafsir al-Mizān. Malang: Penerbit Universitas Negeri Malang.

Yakin, M. Ainul. (2005). Pendidikan Multikultural; Cross-Cultural Understanding untuk Demokrasi dan Keadilan. Yogyakarta: Pilar Media. Google Scholar

Yetkin, Yeldirim. (2009). "The Medina Charter: A Historical Case of Conflict Resolution". Journal Islam and Christian-Muslim Relations 20 (4), 439-450. https:// doi.org/10.1080/09596410903194894

Yusuf, Muhammad, Nahdhiyah, \& Ismail. (2019). "Dimension of Human Perfection Based on Quran" International Journal of Opcion 35(89), 409. Google Scholar

Yusuf, Muhammad. (2014). Horizon Kajian Alquran: Pendekatan dan Metode. Makassar: Alauddin University Press. Google Scholar

Yusuf, Muhammad. (2015). "Anthropological Approach to the Interpretation of the Qur'an", International seminar on "Islamic Civilization Centre LP2M of Alauddin State Islamic University of Makassar on developing Islamic Civilization Empire in Indonesia: the Challenge and Expectation" November 25-26, 2015 at the Training Center of UIN Alauddin Makassar.

Yusuf, Muhammad. (2020). Relasi Teks dan Konteks: Memahami Hadis-Hadis Kontradiktif Melalui Manhaj Imam Syafii. Jogyakarta: Indie Book Corner. Google Scholar

Copyright Holder :

(C) Yusuf, M., \& Abubakar, A., Mardan, M., Nahdhiyah, N., \& Rahim, A., (2020).

First Publication Right :

(C) IJoASER (International Journal on Advanced Science, Education, and Religion)

This article is under:

CC BY SA 